\author{
ЛУТКОВСБКА С. М.,
кандидат педагогічних наук,
доцент кафедри адміністративного
менеджменту та альтернативних
джерел енергї, \\ РИНОК ЗЕРНА: \\ ПРОБЛЕМИ, МОЖЛИВОСТІ \\ ТА ПРІОРИТЕТНІ \\ НАПРЯМИ РОЗВИТКУ \\ КАЗЬМІР В.А., \\ директор відокремленого \\ структурного підрозділу \\ «Могилів-Подільський технолого- \\ економічний фаховий коледж \\ Вінницького національного \\ аграрного університету", \\ Вінницький національний \\ аграрний університет \\ (м. Вінниця)
}

Проведене дослідження дозволило виявити проблеми, дослідити сильні й слабкі сторони, розглянути загрози й альтернативні можливості та визначити пріоритетні напрями розвитку зернового ринку України. Зокрема, у статті зазначено, щзо ринок зерна ие складна економічна система, на яку мають суттєвий вплив природно-кліматичні чинники, показники попиту, пропозиції ціноутворення, державного регулювання, ефективність інститутів, існування відповідної інфраструктури, гострота конкурентної боротьби суб'єктів господарювання тощьо. На макрорівні на ефективність функиіонування зернового ринку мають вплив такі ключові чинники: екологічні (зміна клімату); демографічні (зростання чисельності населення); енергетичні (вирощування зернових на біопаливо); привабливість ринку зерна для ТНК та транснаціональних зернотрейдерів; нерозвиненість інфраструктури зернового ринку; нестача дієвих інструментів державного регулювання щодо попиту та пропозичії на зерновому ринку; низький рівень кредитного забезпечення (високий рівень відсоткових ставок); недосконалість страхового захисту; низька ефективність бюджетної підтримки сільськогосподарських виробників. Пріоритетними напрямами розвитку зернового ринку визнано: удосконалення нормативно-правового поля щзодо функиіонування ринку зерна; удосконалення протекиійних заходів щодо суб'єктів зернового ринку; оптимізачія землеволодіння і землекористування; упровадження дієвого страхового захисту; модернізація матеріально-технічної бази суб'єктів господарювання; створення інформаційного порталу на основі е-логістики та діджиталізації (моніторинг, прогнозування); розвиток експортного потенціалу зернового ринку; забезпечення рівних економічних умов для усіх суб'єктів зернового ринку; удосконалення державної підтримки; сприяння аграрній інтеграџіï та кооперащіï; підвищення компетентністного рівня керівників та менеджерів суб'єктів господарювання; диверсифікація використання зернових культур; запровадження нових інструментів кредитного та інвестиційного забезпечення; розвиток інфраструктури зернового ринку; упровадження е-логістики. 
Ключові слова: ринок зерна, пріоритетні напрями, розвиток ринку зерна, зернові та зернобобові культури, суб'єкти господарювання, державне регулювання ринку зерна.

Рис.: 1. Табл. : 3. Літ.: 8.

\title{
GRAIN MARKET: PROBLEMS, OPPORTUNITIES AND PRIORITIES OF DEVELOPMENT
}

\author{
LUTKOVSKA Svitlana,
Candidate of Pedagogical Sciences, \\ LUTKOVSKA Svitlana,
Candidate of Pedagogical Sciences, \\ Associate Professor of the \\ Department of Administrative \\ Management and alternative energy sources, \\ Management and alternative energy sources,
}

KAZMYR Valentyna, Director Mohyliv-Podilskyi College of Technology and Economics, Vinnytsia National Agrarian University

(Vinnytsia) weaknesses, consider threats and alternative opportunities and identify priority areas for development of the grain market of Ukraine. In particular, it is noted that the grain market is a complex economic system, which is significantly influenced by climatic factors, demand, supply, pricing, government regulation, efficiency of institutions, the existence of appropriate infrastructure, the intensity of competition of economic entities and more. At the macro level, the efficiency of the grain market is influenced by the following key factors: environmental (climate change); demographic (population growth); energy (growing cereals for biofuels); attractiveness of the grain market for TNCs and transnational grain traders; underdeveloped infrastructure of the grain market; lack of effective instruments of state regulation of supply and demand in the grain market; low level of credit security (high level of interest rates); imperfection of insurance protection; low efficiency of budget support for agricultural producers. Priority areas for the development of the grain market are: improvement of the regulatory framework for the functioning of the grain market; improvement of protection measures for grain market entities; optimization of land tenure and land use; introduction of effective insurance protection; modernization of material and technical base of business entities; creation of an information portal based on e-logistics and digitalization (monitoring, forecasting); development of the export potential of the grain market; ensuring equal economic conditions for all subjects of the grain market; improving state support; promotion of agrarian integration and cooperation; raising the competence level of managers and managers of business entities; diversification of grain use; introduction of new credit and investment collateral instruments; development of grain market infrastructure; introduction of e-logistics.

Key words: grain market, priority directions, development of grain market, grain and leguminous crops, business entities, state regulation of grain market.

Fig.: 1. Tabl.: 3. Ref.: 8.

\section{РЫНОК ЗЕРНА: ПРОБЛЕМЫ, ВОЗМОЖНОСТИ И ПРИОРИТЕТНЫЕ НАПРАВЛЕНИЯ РАЗВИТИЯ}

ЛУТКОВСКАЯ С. М., кандидат педагогических наук, 


\section{КАЗЬМИР В. А., директор обособленного структурного подразделения «Могилев-Подольский технолого-экономический профессиональный колледж Винницкого национального аграрного университета», Винницкий национальный аграрный университет} (2. Винница)

В статье проведено исследование позволило выявить проблемы, исследовать сильные и слабые стороны, рассмотреть угрозы и альтернативные возможности и определить приоритетные направления развития зернового рынка Украины. В частности, отмечено, что рынок зерна представляет собой сложную экономическую систему, на которую имеют существенное влияние природно-климатические факторы, показатели спроса, предложения, ценообразования, государственного регулирования, эффективность институтов, существование соответствующей инфраструктуры, острота конкурентной борьбы субъектов хозяйствования и тому подобное. На макро уровне на эффективность функиионирования зернового рынка влияют следуюшие ключевые факторы: экологические (изменение климата) демографические (рост численности населения); энергетические (вырашивание зерновых на биотопливо) привлекательность рынка зерна для ТНК и транснациональных зернотрейдеров; неразвитость инфраструктуры зернового рынка; недостаток действенных инструментов государственного регулирования относительно спроса и предложения на зерновом рынке; низкий уровень кредитного обеспечения (высокий уровень прочентных ставок); несовершенство страховой защиты; низкая эффективность бюджетной поддержки сельскохозяйственных производителей. Приоритетными направлениями развития зернового рынка признаны: совершенствование нормативноправового поля по функиионированию рынка зерна; совершенствование протекиионных мероприятий в отношении субъектов зернового рынка; оптимизация землевладения $u$ землепользования; внедрение действенного страховой защиты; модернизачия материальнотехнической базы субъектов хозяйствования; создание информачионного портала на основе электронной логистики и диджитализации (мониторинг, прогнозирование); развитие экспортного потенциала зернового рынка; обеспечение равных экономических условий для всех субъектов зернового рынка; совершенствование государственной поддержки; содействие аграрной интеграции и коопераџии; повымение компетентностного уровня руководителей и менеджеров субъектов хозяйствования; диверсификация использования зерновых культур; внедрения новых инструментов кредитного и инвестиционного обеспечения; развитие инфраструктуры зернового рынка; внедрение е-логистики.

Ключевые слова: рынок зерна, приоритетные направления, развитие рынка зерна, зерновые и зернобобовые культуры, субъекты хозяйствования, государственное регулирование рынка зерна.

Рис.: 1. Табл. : 3. Лит.: 8.

Постановка проблеми. Сприятливі природно-кліматичні чинники та висока родючість грунтів на теренах України дають змогу вирощувати високі врожаї зернових й зернобобових культур, що дозволяє забезпечувати продовольчим зерном внутрішні та експортні потреби країни. «Зернова галузь 
формує експортний потенціал і $є$ однією 3 найважливіших у складі АПК України» [2].

Виробництво зерна $\epsilon$ стратегічною i високоефективною галуззю національної економіки та вважається базою продовольчої безпеки держави. Зерновий ринок має забезпечувати рівноважний попит і пропозицію передусім за рахунок власних джерел, що потребує побудови відповідного результативного організаційно-економічного механізму його функціонування, дієвих державних регуляторних інструментів, захисних заходів для підтримки вітчизняних товаровиробників, формування відповідних інститутів та необхідної інфраструктури. Вище зазначене підтверджує актуальність виявлення проблем, розгляду альтернативних можливостей та визначення пріоритетних напрямів розвитку зернового ринку України.

Аналіз останніх досліджень і публікацій. Питання формування й розвитку зернового ринку в умовах кризових потрясінь розглядалися у працях таких відомих вчених, як Л. Вдовенко, П. Гайдуцький, В. Жук, Г. Калетнік, І. Кириленко, Т. Лозинська, Ю. Лузан, В. Мазур, П. Макаренко, М. Малік, М. Месель-Веселяк, Н. Правдюк, П. Саблук., І. Свиноус, М. Сікало, Л. Худолій, О. Шпикуляк та ін. Високо оцінюючи їхні наукові розробки в царині державного регулювання й кон'юнктури зернового ринку, підвищення економічної ефективності виробництва зерна, удосконалення механізму ціноутворення та зростання конкурентоспроможності, усе ж варто відзначити, що в сучасних умовах широкопланового впливу пандемї COVID-19 на параметри економічного простору, виявлення проблем, розгляд альтернативних можливостей та визначення пріоритетних напрямів розвитку зернового ринку України вважаємо вкрай необхідним.

Метою статті $\epsilon$ виявлення проблем, розгляд альтернативних можливостей та визначення пріоритетних напрямів розвитку зернового ринку України.

Виклад основного матеріалу дослідження. Зернові й зернобобові культури традиційно мали велике значення для національної економіки України. I не даремно видатний вчений А. Сміт зазначав: «...лише надлишковий продукт села або той продукт, що перевищує потребу утримання хліборобів, дає місту засоби існування, а тому останнє може рости й розвиватися тільки в міру збільшення цього надлишкового продукту» [6, с. 234].

Ринок зерна - це складна економічна система, на яку мають суттєвий вплив природно-кліматичні чинники, показники попиту, пропозиції, ціноутворення, державного регулювання, ефективність інститутів, існування відповідної інфраструктури, гострота конкурентної боротьби суб’єктів господарювання тощо. Тому, для забезпечення ефективного функціонування ринку зерна потрібний дієвий організаційно-економічний механізм.

«Зернові культури займають понад 14 млн га або 56 \% у структурі посівних площ. Наявний потенціал та географічне розташування дає змогу формувати експортні партії зернових культур та вести активну зовнішньоекономічну діяльність» [3]. 
Кризові явища кінця 90-х років минулого століття мали істотний негативний вплив на розвиток сільського господарства та зокрема й на виробництво зернових і зернобобових культур. У середньому виробництво зернових в Україні у 1986 - 1991 роках складало 47,4 млн т, уже за наступні 5 років (1991 - 1995 рр.), воно становило - 38 млн т, а у 2000 р. впало до 24,5 млн т, і лише пізніше почало повільно зростати (у 2010 р. - 39,3 млн т, у 2011 р. - 56,7 млн т, у 2015 - 60,1, у 2018 - 70,1, у 2019 - 75,1 млн т) (рис. 1) [4].

Цікаво, що деякі науковці занепокоєні таким швидким нарощенням зернового виробництва. Л. Шавалюк стверджує, що «стрімкий розвиток зернового господарства може цілковито змінити українське село, в якому нині проживає 31\% населення (більше, ніж 14 млн осіб). Сучасні технології забезпечують високу продуктивність праці, отож згодом для обробітку всіх земель в Україні буде потрібно мало людей і постане серйозна проблема із зайнятістю сільського населення. Крім того, великий бізнес, який на сучасному етапі активно вкладає гроші в АПК, у гонитві за швидкими прибутками робить ставку на вирощування культур, які виснажують землю, зокрема технічних. Натомість посіви традиційних продовольчих культур стрімко зменшуються. За такої динаміки розподілу площ неминуче знижуватиметься також родючість українських чорноземів» [7].

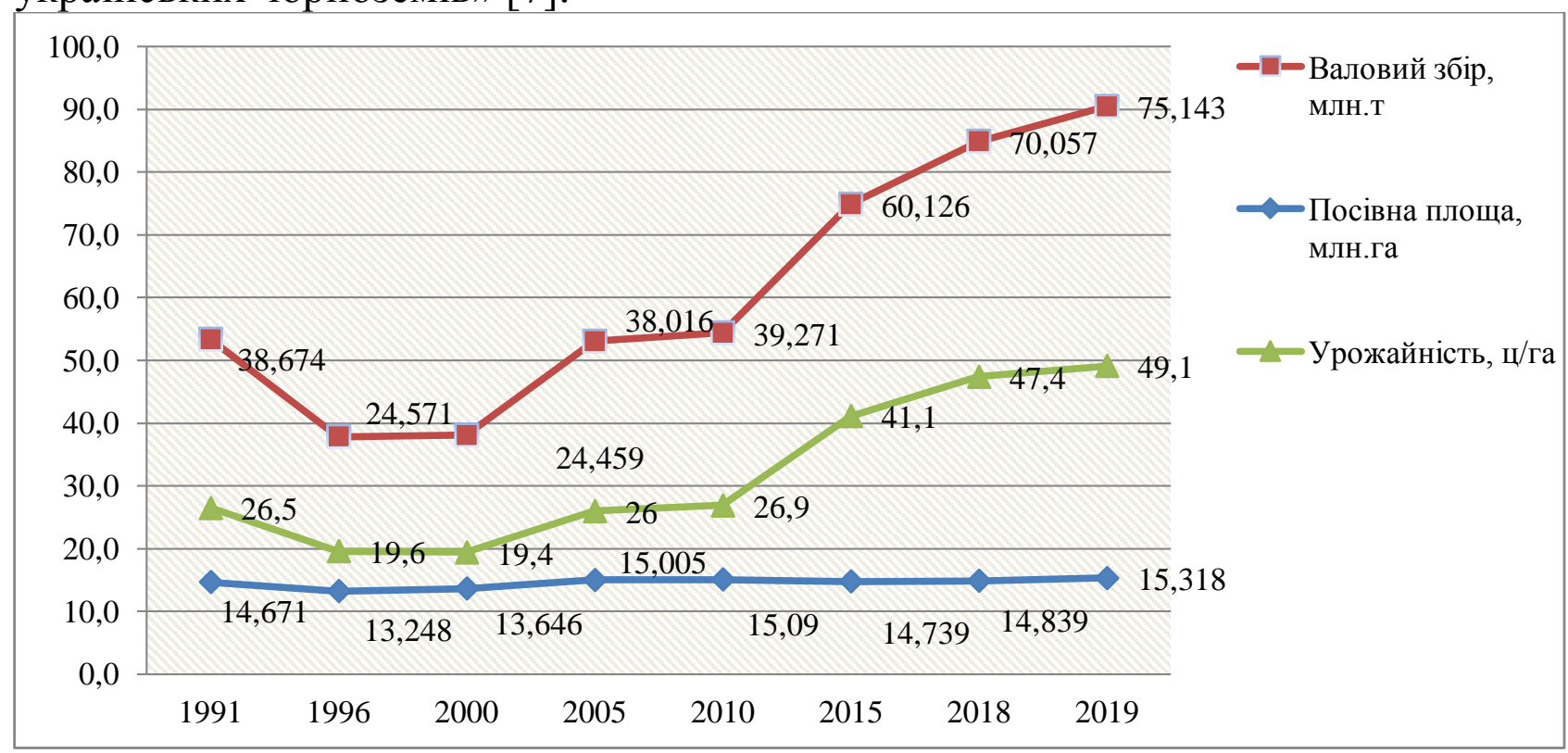

Рис. 1. Динаміка посівних площ, валового збору та урожайності зернових та зернобобових культур у 1991 - 2019 рр.

Джерело: побудовано авторами за [4]

Варіативне коливання посівних площ спостерігалось у діапазоні 1,297, валового збору - 3,713, а урожайності - 2,697, що підтверджує високу ризикованість виробництва зерна.

Динаміка урожайності зернових та зернобобових культур за період 2000 2019 рр. представлена у таблиці 1. 
EФМ

http://efm.vsau.org/

Таблиия 1

Динаміка урожайності зернових та зернобобових культур за період $2000-2019$ рp., ц / га

\begin{tabular}{|c|c|c|c|c|c|c|c|c|}
\hline \multirow{2}{*}{ Показник } & \multicolumn{8}{|c|}{ Рік } \\
\hline & 2000 & 2005 & 2010 & 2015 & 2016 & 2017 & 2018 & 2019 \\
\hline $\begin{array}{l}\text { Культури } \\
\text { зернові та } \\
\text { зернобобові }\end{array}$ & 19,4 & 26,0 & 26,9 & 41,1 & 46,1 & 42,5 & 47,4 & 49,1 \\
\hline \multicolumn{9}{|l|}{ у тому числі } \\
\hline пшениця & 19,8 & 28,5 & 26,8 & 38,8 & 42,1 & 41,1 & 37,3 & 41,6 \\
\hline озима & 20,0 & 29,0 & 27,1 & 38,9 & 42,2 & 41,2 & 37,3 & 41,6 \\
\hline яра & 15,4 & 21,8 & 21,0 & 35,1 & 38,7 & 38,0 & 35,8 & 40,0 \\
\hline жито & 15,2 & 17,3 & 16,7 & 25,9 & 27,3 & 29,6 & 26,6 & 28,9 \\
\hline озиме & 15,2 & 17,3 & 16,6 & 25,9 & 27,3 & 29,7 & 26,6 & 28,9 \\
\hline яре & 16,3 & 14,7 & 24,4 & 27,8 & 26,3 & 22,3 & 18,4 & 30,0 \\
\hline ячмінь & 18,6 & 20,6 & 19,7 & 29,5 & 33,0 & 33,1 & 29,6 & 34,2 \\
\hline озимий & 18,9 & 21,2 & 22,4 & 31,2 & 36,2 & 34,4 & 33,5 & 36,7 \\
\hline ярий & 18,6 & 20,6 & 18,3 & 28,5 & 31,3 & 32,4 & 27,5 & 32,4 \\
\hline овес & 18,3 & 17,6 & 14,8 & 23,2 & 24,0 & 23,9 & 21,4 & 23,2 \\
\hline просо & 11,6 & 11,7 & 13,7 & 18,9 & 17,6 & 15,0 & 14,6 & 18,1 \\
\hline гречка & 9,1 & 6,9 & 6,7 & 10,0 & 11,5 & 9,7 & 12,1 & 12,3 \\
\hline рис & 35,6 & 43,4 & 50,5 & 53,4 & 53,9 & 50,5 & 54,9 & 52,2 \\
\hline кукурудза на зерно & 30,1 & 43,2 & 45,1 & 57,1 & 66,0 & 55,1 & 78,4 & 71,9 \\
\hline сорго & 11,5 & 26,8 & 21,4 & 37,2 & 38,9 & 27,9 & 46,3 & 40,8 \\
\hline $\begin{array}{l}\text { культури } \\
\text { зернобобові }\end{array}$ & 17,0 & 18,9 & 15,1 & 20,4 & 27,3 & 24,6 & 17,2 & 20,4 \\
\hline
\end{tabular}

Джерело: розраховано авторами за [4]

Дані таблиці 1 засвідчують, що не зважаючи на високу якість грунтів, середня урожайність зернових та зернобобових культур в Україні за останні роки нижча, ніж у європейських країнах. Такий стан науковці пояснюють використанням застарілої матеріально-технічної бази, неякісним насіннєвим матеріалом, обмеженістю використання інноваційних технологій, недоступністю кредитних ресурсів. «Особливо це стосується господарств населення та малих фермерських господарств із урожайністю зерна близько 80\% середнього іiі рівня по Україні»[4].

Динаміка валової продукції, експорту та імпорту зернових та зернобобових культур у 2010 - 2019 роках висвітлена у таблиці 2.

Цікаво, що «частка України у світовій торгівлі зерном збільшилася з 1 до 10 \%. Україна входить до першої десятки експортерів пшениці, займає перше місце на світовому ринку з експорту ячменю» [8].

«Україна експортує зерно в 78 країн світу: країни СНД, СС, Близького Сходу, країни басейну Тихого океану» [4].

«Україна входить до трійки найбільших експортерів зерна у світі» [5, с. 83]. Акцентуємо, що експорт зерна у структурі аграрної галузі сягає майже 40\%. Суттєвою проблемою при цьому є низька якість зернової продукції (майже 60 \% - це фуражне зерно), що впливає на рівень цін.

Н.Л. Правдюк Н.Л. та А.О. Ярославський обгрунтовують, що «зерновий сектор займає одне з ключових місць у структурі аграрної економіки України, 
формуючи понад чверть загального виробництва сільськогосподарської продукції» [5, с. 82].

Табличя 2

Динаміка валової продукції, експорту та імпорту зернових та зернобобових культур у $2010-2019$ рр.

\begin{tabular}{|l|c|c|c|c|c|c|}
\hline \multirow{2}{*}{ Показник } & \multicolumn{5}{|c|}{ Рік } \\
\cline { 2 - 7 } & 2010 & 2015 & 2016 & 2017 & 2018 & 2019 \\
\hline $\begin{array}{l}\text { Валова } \\
\text { продукція, млн } \\
\text { грн. }\end{array}$ & 126803,3 & 193390,3 & 211762,4 & 198633,1 & 225618,7 & 239728,2 \\
\hline Частка, \% & 27,1 & 32,4 & 33,4 & 32,0 & 33,6 & 35,2 \\
\hline $\begin{array}{l}\text { Експорт , тис. } \\
\text { дол. США }\end{array}$ & 2467060,7 & 6057490,0 & 6073915,3 & 6501134,3 & 7240558,1 & 9633333,9 \\
\hline Частка, \% & 24,9 & 41,6 & 39,7 & 36,6 & 38,9 & 43,5 \\
\hline $\begin{array}{l}\text { Імпорт, тис. дол. } \\
\text { США }\end{array} 145583,5$ & 154707,7 & 148799,7 & 176756,1 & 191116,7 & 180817,4 \\
\hline Частка, \% & 2,5 & 4,4 & 3,8 & 4,1 & 3,8 & 3,2 \\
\hline
\end{tabular}

Джерело: розраховано авторами за [4]

Рівень рентабельності виробництва зернових та зернобобових культур у 1991-2019 роках та для порівняння рівень рентабельності сільського господарства й продукції рослинництва висвітлено у таблиці 3 , а також довідково наведено середні ціни на зернові та зернобобові культури.

Сучасний ринок зерна характеризується стрімкими непрогнозованими змінами, відсутністю збутового паритету, нестабільністю регуляторної політики, ціновим диспаритетом. Тому для постійного об’єктивного моніторингу ринку зерна доцільне створення спеціального інформаційного порталу.

Г.М. Калетнік 3 іншими дослідниками обгрунтовували, що «сучасний період розвитку держави потребує переходу від регламентації виробничогосподарської та фінансової діяльності юридичних і фізичних осіб до регулювання економічних процесів за допомогою економічних $\mathrm{i}$ правових підойм. Необгрунтована експансія державного впливу практично на всі процеси в суспільстві є не меншою загрозою, ніж повне нівелювання ії функціональних можливостей. Необхідність оптимального поєднання державних функцій із принципами ринкового саморегулювання залишається наріжним каменем теорії добробуту та теорії державної політики. Таким чином, на сьогодні метою державного управління і регулювання є забезпечення переходу від хаотичних економічних процесів до регульованих» [1].

На макрорівні на ефективність функціонування зернового ринку мають вплив такі ключові чинники:

- екологічні (зміна клімату) та демографічні (зростання чисельності населення);

- енергетичні (вирощування зернових на біопаливо);

- привабливість ринку зерна для ТНК та транснаціональних зернотрейдерів; 
- нерозвиненість інфраструктури зернового ринку та нестача дієвих інструментів державного регулювання щодо попиту та пропозиції на зерновому ринку;

- низький рівень кредитного забезпечення (високий рівень відсоткових ставок) та недосконалість страхового захисту;

- низька ефективність бюджетної підтримки сільськогосподарських виробників.

Табличя 3

Рівень рентабельності виробництва зернових та зернобобових культур у $1991-2019$ рр.

\begin{tabular}{|c|c|c|c|c|}
\hline Рік & $\begin{array}{c}\text { Продукція } \\
\text { сільського } \\
\text { господарства, \% }\end{array}$ & $\begin{array}{c}\text { Продукція } \\
\text { рослинництва, } \\
\%\end{array}$ & $\begin{array}{c}\text { Зернових та } \\
\text { зернобобових, \% }\end{array}$ & $\begin{array}{c}\text { Довідково: } \\
\text { середні ціни, грн/т }\end{array}$ \\
\hline 1991 & 56,2 & 114,6 & 275,1 & 94,3 \\
\hline 1996 & $-11,7$ & 29,7 & 64,6 & 168,4 \\
\hline 2000 & $-1,0$ & 30,8 & 64,8 & 443,8 \\
\hline 2003 & 12,6 & 41,7 & 45,8 & 535,1 \\
\hline 2005 & 6,8 & 7,9 & 3,1 & 417,8 \\
\hline 2010 & 21,1 & 26,7 & 13,9 & 1120,9 \\
\hline 2013 & 11,2 & 11,1 & 1,5 & 1299,8 \\
\hline 2015 & 30,4 & 36,7 & 43,1 & 2912,1 \\
\hline 2017 & 16,5 & 20,4 & 25,0 & 3771,6 \\
\hline 2018 & 14,2 & 18,7 & 24,7 & 4315,0 \\
\hline 2019 & 16,1 & 13,6 & 11,8 & 3867,5 \\
\hline Коливання $\max / \mathrm{min}$ & 67,9 & 106,7 & 273,6 & - \\
\hline
\end{tabular}

Джерело: розраховано авторами за [3]

Здійснений SWOT-аналіз демонструє, що сильними сторонами вітчизняного зернового ринку є: висока родючість грунтів; дешева робоча сила; наявність експортної інфраструктури.

Слабкими сторонами вітчизняного зернового ринку варто вважати: низька якість зерна; застарілі технології; нестабільність національної валюти; висока собівартість; низькі ціни; нестабільність державного регулювання; висока частка тіньового обігу зерна; низька урожайність; недостатня компетентність менеджменту; недостатнє фінансування інтервенцій; зношеність матеріальнотехнічної бази; недотримання вимог агрокультури й сівозмін; низька кваліфікація праці працівників; слабке фінансове забезпечення суб'єктів господарювання; низька інтеграція суб'єктів ринку; потреба в об'єктивному плануванні та стратегіях розвитку; нерозвиненість біржової торгівлі; низький рівень внесення мінеральних добрив та засобів захисту рослин; недостатнє інвестиційне забезпечення інфраструктури зернового ринку.

До можливостей розвитку вітчизняного зернового ринку можна віднести: збільшення частки високоякісного зерна; підвищення частки експорту; розширення експортного асортименту; використання зерна для виробництва етанолу; підвищення цін на зерно на світових ринках.

Загрозами розвитку вітчизняного зернового ринку доцільно вважати: погіршення якісних характеристик грунтів; велика кількість дрібних 
землевласників; неефективність державного регулювання; істотні коливання цін на зерно; мінливість кліматичних умов; падіння платоспроможності населення; загострення конкурентної боротьби; непрогнозованість міграційних процесів; відсутність достатніх запасів зерна; зростання валютних ризиків; незбалансованість виробничої інфраструктури; старіння сільського населення.

Опираючись на проведене дослідження пріоритетними напрямами розвитку зернового ринку доцільно визнати:

- удосконалення нормативно-правового поля щодо функціонування ринку зерна;

- удосконалення протекційних заходів щодо суб’єктів зернового ринку;

- оптимізація землеволодіння і землекористування;

- упровадження дієвого страхового захисту;

- модернізація матеріально-технічної бази суб'єктів господарювання;

- створення інформаційного порталу на основі е-логістики та діджиталізації (моніторинг, прогнозування);

- розвиток експортного потенціалу зернового ринку;

- забезпечення рівних економічних умов для усіх суб'єктів зернового ринку та вдосконалення державної підтримки (цільові програми, податкові преференції тощо);

- сприяння аграрній інтеграції та кооперації;

- підвищення компетентністного рівня керівників та менеджерів суб’ єктів господарювання;

- диверсифікація використання зернових культур (виробництво біоетанолу);

- запровадження нових інструментів кредитного та інвестиційного забезпечення;

- розвиток інфраструктури зернового ринку (припортові елеватори, транспортні ланцюги тощо);

- упровадження е-логістики.

Висновки. Проведене дослідження дозволило виявити проблеми, дослідити сильні й слабкі сторони, розглянути загрози й альтернативні можливості та визначити пріоритетні напрями розвитку зернового ринку України. Зокрема, відзначено, що ринок зерна - це складна економічна система, на яку мають суттєвий вплив природно-кліматичні чинники, показники попиту, пропозиції, ціноутворення, державного регулювання, ефективність інститутів, існування відповідної інфраструктури, гострота конкурентної боротьби суб'єктів господарювання тощо. Пріоритетними напрямами розвитку зернового ринку визнано: удосконалення нормативно-правового поля щодо функціонування ринку зерна; удосконалення протекційних заходів щодо суб'єктів зернового ринку; оптимізація землеволодіння і землекористування; впровадження дієвого страхового захисту; модернізація матеріально-технічної бази суб'єктів господарювання; створення інформаційного порталу на основі е- 
логістики та диджиталізації (моніторинг, прогнозування); розвиток експортного потенціалу зернового ринку; забезпечення рівних економічних умов для усіх суб'єктів зернового ринку; удосконалення державної підтримки (цільові програми, податкові преференції тощо); сприяння аграрній інтеграції та кооперації; підвищення компетентнісного рівня керівників та менеджерів суб'єктів господарювання; диверсифікація використання зернових культур (виробництво біоетанолу); запровадження нових інструментів кредитного та інвестиційного забезпечення; розвиток інфраструктури зернового ринку (припортові елеватори, транспортні ланцюги тощо); упровадження е-логістики.

\section{Список використаних джерел}

1. Калетнік Г. М., Мазур А. Г., Кубай О. Г. Державне регулювання економіки: Навчальний посібник. Київ: «Хай-Тек Прес». 2011. 428 с.

2. Кобута І.В. Державна політика регулювання цін та аграрних ринків э у 2009 році: дотримання зобов’ язань перед СОТ. Облік і фінанси АПК. 2009. № 4. C. $170-176$.

3. Лузан Ю.Я. Збалансованість попиту та пропозицій на продовольчому ринку України. Економіка АПК. 2011. № 8. С. 27-36.

4. Державна служба статистики України. Офіційний сайт. URL : http://www.ukrstat.gov.ua (дата звернення: 1.09.2020).

5. Правдюк Н.Л., Ярославський А.О. Формування організаційноекономічного механізму управління економічною безпекою зернопереробних підприємств. Економіка. Фінанси. Менеджмент: актуальні питання науки $i$ практики. 2019. № 8. С. 77-85.

6. Сміт А. Добробут наиії: дослідження про природу та причини добробуту наиій: під ред. С. Литвин. Київ: Port Royal, 2001. 594 с.

7. Шавалюк Л. Міф про Україну - житницю світу. Чому аграрний сектор не може стати локомотивом економіки. Украӥнський тиждень. № 33 (301). URL : http://tyzhden.ua/Economics/87077. (дата звернення: 10.11.2019)

8. Яковлева Н. Зерно врятує Україну від дефолту. URL: http:// novynar.com.ua/analytics/economics (дата звернення: 11.12.2019)

\section{References}

1. Kaletnik G.M., Mazur A.G. \& Kubai O.G. (2011). Derzhavne rehuliuvannia ekonomiky: Navchalnyi posibnyk. Kyiv: «Khai-Tek Pres». 428 [in Ukrainian].

2. Kobuta I.V. (2009). Government policy to regulate prices and agricultural markets in 2009: compliance with WTO obligations [Derzhavna politika regulyuvannya cin ta agrarnih rinkiv u 2009 roci: dotrimannya zobovyazan pered SOT]. Oblik i finansi APK - Accounting \& Finance APK, 4, 170-176 [in Ukrainian].

3. Luzan U. Ya. (2011). Balance of supply and demand in the food market of Ukraine [Zbalansovanist popitu ta propozicij na prodovolchomu rinku Ukraïni]. Ekonomika APK-Ekonomika APK, 2011, 8, 27-36 [in Ukrainian]. 
4. Derzhavna sluzhba statystyky Ukrainy [State Statistics Service of Ukraine]. URL: http://www.ukrstat.gov.ua/ (data zvernennia: 01.09.2020) [in Ukrainian].

5. Pravdiuk N.L. \& Yaroslavskyi A.O. (2019). Theoretical aspects of formwave organization-economic mechanism management of the economic successfully of grain convergence pidpries [Formuvannia orhanizatsiinoekonomichnoho mekhanizmu upravlinnia ekonomichnoiu bezpekoiu zernopererobnykh pidpryiemstv]. Ekonomika. Finansy. Menedzhment: aktualni pytannia nauky i praktyky - Economy, finances, management: Topical issues of sciense and practical activity, 8, 77-85 [in Ukrainian].

6. Smith, A. (2001). Dobrobut nazii: doslidgenia pro prirosu i prichinu sobrobutu nazi. Port Royal, Kiev, 594 [in Ukrainian].

7. Shavalyuk L. The myth of Ukraine - the breadbasket of the world. Why the agricultural sector cannot become the locomotive of the economy [Mif pro Ukraïnu - zhitnicyu svitu. Chomu agrarnij sektor ne mozhe stati lokomotivom ekonomiki]. Ukraïnskij tizhden - Ukrainian week, 33 (301). URL: http://tyzhden.ua/Economics/87077 (data zvernennia: 10.11.2019).

8. Yakovleva N. Grain will save Ukraine from default [Zerno vryatue Ukraïnu vid defoltu]. URL: http://novynar.com.ua/analytics/economics] (data zvernennia: 11.12.2019).

\section{Відомості про авторів}

ЛУТКОВСБКА Світлана Михайлівна - кандидат педагогічних наук, доцент кафедри адміністративного менеджменту та альтернативних джерел енергії, Вінницький національний аграрний університет(вул. Сонячна, 3, м. Вінниця, 21008, e-mail: svetvsau@gmail.com).

КАЗЬМІР Валентина Анатоліївна - директор відокремленого структурного підрозділу «Могилів-Подільський технолого-економічний фаховий коледж Вінницького національного аграрного університету», (вул. Сонячна, 3, м. Вінниця, 21008, e-mail: annakazmir@ukr.net).

LUTKOVSKA Svitlana - Candidate of Pedagogical Sciences, associate Professor, Department of Administrative Management and Alternative Energy Sources, Vinnytsia National Agrarian University (21008, Vinnytsia, 3 Soniachna st, email: svetvsau@gmail.com).

KAZMYR Valentyna - Director Mohyliv-Podilskyi College of Technology and Economics, Vinnytsia National Agrarian University (21008, Vinnytsia, Soniachna str. 3, e-mail: annakazmir@ukr.net ).

ЛУТКОВСКАЯ Светлана Михайловна, кандидат педагогических наук, доцент кафедры административного менеджмента и альтернативных источников энергии, Винницкий национальный аграрный университет (ул. Солнечная, 3, г. Винница, 21008, e-mail: svetvsau@gmail.com).

КАЗЬМИР Валентина Анатольевна - директор обособленного структурного подразделения «Могилев-Подольский технолого-экономический 
профессиональный колледж Винницкого национального аграрного университета», Винницкий национальный аграрный университет (21008, г. Винница, ул. Солнечная, 3, e-mail: annakazmir@ukr.net).

\title{
ЕКОНОМІКА ТА ЕФЕКТИВНІСТЬ ВИРОБНИЧО-ГОСПОДАРСЬКОЇ ДІЯЛЬНОСТІ ПІДПРИЕМСТВ
}

\author{
UDK 631.11:005.332.4 \\ DOI: 10.37128/2411-4413-2020-3-4
}

\begin{abstract}
COMPETITIVENESS OF
UKRAINIAN

AGRICULTURAL

ENTERPRISES AT THE

CURRENT STAGE OF

ECONOMIC

TRANSFORMATIONS

\author{
YURCHUK Natalia, \\ Candidate of Economic Sciences, \\ Associate Professor of the Department of \\ Computer \\ Science and Economic Cybernetics, \\ Vinnytsia National Agrarian University \\ (Vinnytsia)
}

The article examines the theoretical foundations of the concept of competition and competitiveness, identifies the features and parameters of this economic category for Ukrainian agricultural enterprises. It is noted that the level of competitiveness of an agricultural enterprise at certain times is determined by the influence of a number of factors. Factors vary in nature, origin and level of influence, accordingly, effective management of the competitiveness of the agricultural enterprise is possible provided that the factors are identified and scientifically sound classification.

Taking into account that agricultural enterprises have different strategic potential, different strategies and operate in an environment of varying complexity, external and internal are considered; controlled and uncontrolled factors used to assess the level of competitiveness of agricultural enterprises.

It is determined that the assessment of competitiveness is an integral part of any enterprise, because only on the basis of such an assessment can be drawn conclusions about the level of competitiveness of the enterprise, as well as develop directions for its improvement. It was found that the methodology of competitiveness research is directly dependent on the globalization of goals. Most methods of assessing competitiveness are based on identifying factors that affect the competitiveness of the enterprise. It is noted that the assessment of the competitiveness of the enterprise should take into account the criteria for its implementation. It is also established that an effective way to reduce the cost of agricultural production is the use of alternative fuels, in particular, biodiesel and bioethanol, which can replace expensive traditional fuels. The directions of state support of agricultural enterprises, the size of subsidies and subsidies as one of the important elements of ensuring their continuous operation and increasing competitiveness are studied. According to the results of the study, the areas of increasing the competitiveness of Ukrainian agricultural enterprises in an innovative environment, the implementation of which for a long time will create real advantages over competitors.
\end{abstract}

Key words: competition, competitiveness, competitiveness of agricultural enterprises, factors influencing competitiveness, assessment of competitiveness of enterprises, state support.

Fig.: 4. Lit.: 21. 